\title{
APAKAH YANG MEMENGARUHI KESADARAN MAHASISWA ATAS PAJAK?
}

\author{
ASTRI NUR KOMALA, TRISMAYARNI ELEN* \\ Universitas Prof. Dr. Moestopo (Beragama) \\ *Email: elen.akuntan@gmail.com
}

\begin{abstract}
The objective of study is to analyze affect of tax education, tax training and tax assessment on student awareness of tax. The research sample are 101 respondents who were active students in the Tax Center with accidental sampling techniques in several universities in Jakarta area. Multiple regression was used to test hypothesis to analyze affect of factors that student awereness of tax. The result of this study shows that there has no a positive and not significant effect on tax education, but there has a positive and significant effect on tax training and tax assesment on student awareness of tax.
\end{abstract}

Keywords: Tax Assessment; Tax Education; Tax Training; Student Awareness of Tax.

\section{PENDAHULUAN}

Dalam upaya meningkatkan penerimaan pajak, Direktorat Jenderal Pajak (DJP) dituntut untuk meningkatkan kinerja guna mencapai target penerimaan pajak. Salah satu upaya DJP untuk meningkatkan penerimaan pajak yaitu dengan upaya memberikan pendidikan pajak kepada masyarakat agar masyarakat dapat memahami sistem perpajakan dan dapat berperan aktif dalam melaksanakan kegiatan perpajakan.

Kesadaran pajak sangat diharapkan tumbuh di dalam diri mahasiswa karena mahasiswa adalah generasi yang dianggap dapat melakukan perbaikan arah pemikiran tentang pajak. Kesadaran akan pajak bagi mahasiswa sangat sulit terwujud jika mahasiswa tidak memiliki wadah untuk dapat belajar tentang apa dan bagaimana pajak tersebut melalui lembaga yang dapat didirikan oleh badan pemerintah yang berada di lingkungan tempat mahasiswa belajar yaitu kampus atau perguruan tinggi. Wadah tersebut adalah tax center.

Dengan hadirnya tax centerdi lingkungan mahasiswa, maka mahasiswa diharapkan dapat menjadi agen perubahan dan agen dari semua informasi pada lingkungan kampus dan masyarakat agar penerimaan pajak dapat lebih maksimal yang digunakan untuk melanjutkan pembangunan negara Indonesia yang bermartabat. 
Betapa pentingnya memunculkan kesadaran pajak maka pentingnya peran dari tax center yang menjadi pusat informasi perpajakan di lingkungan kampus/perguruan tinggi, maka dilakukan penandatanganan Nota Kesepahaman Pembentukan Tax Center yang berada di Universitas 17 Agustus 1945 yang lebih dikenal dengan Untag bersama Kantor Wilayah Direktorat Jenderal Pajak (Kanwil DJP) wilayah Kalimantan Timur dan Utara (Kaltimra). Penandatanganan yang dilakukan di dalam gedung aula kampus Untag-Samarinda, disaksikan oleh ratusan mahasiswa di dalam Gedung Aula Kampus Untag, Samarinda.

Kepala Kanwil Direktorat Jenderal Pajak Kaltimra Samon Jaya menyampaikan kuliah umum perpajakan kepada para mahasiswa, "Mahasiswa sebagai generasi penerus bangsa dan future tax payer harus punya semangat untuk membangun Indonesia dengan taat dan sadar pajak". Dengan penandatangan nota kesepahaman tersebut maka kedua belah pihak sangat berharap bahwa pusat bagi informasi, pendidikan dan pelatihan perpajakan untuk mahasiswa di kampus dapat dilakukan melalui tax center sehingga mahasiswa dapat ikut berperan dalam mewujudkan masyarakat yang sadar akan pajak. (DJP, 2019)

Menurut (Herryanto \& Toly, 2013), peningkatan pengetahuan pada masyarakat mengenai sistem dan aturan yang berlaku di Indonesia seharusnya dilakukan oleh pemerintah, terutama mengenai bagaimana cara kewajiban perpajakan dijalankan yang sesuai dengan aturan dan perundangan yang berlaku. Sehingga jika kesadaran masyarakat meningkat tentang perpajakan diharapkan dapat melahirkan generasi baru Wajib Pajak yang menyadari bahwa betapa pentingnya penerimaan negara dari sektor pajak untuk membangun bangsa dan negara.

Karena kesadaran wajib pajak berkaitan erat dengan kepatuhan wajib pajak, (Triandani \& Apollo, 2020). Apabila wajib pajak memiliki kesadaran yang tinggi yang bersumber dari motivasi membayar pajak, maka dengan sendirinya akan mempengaruhi kemauan untuk membayar pajak, dan selanjutnya akan meningkatkan penerimaan negara dari pajak.

\section{LANDASAN TEORI}

\section{Teori Implementasi}

Menurut Van Meter dan Van Horn, dalam (Wahab, 2012), suatu tindakan yang dilakukan oleh baik individu-individu, pejabat-pejabat juga kelompokkelompok pemerintah atau swasta dan diarahkan kepada pencapaian tujuan-tujuan yang digariskan di dalam keputusan kebijakan, merupakan definisi dari implementasi.

Menurut Friedrich, dalam (Wahab, 2012), kebijakan adalah suatu tindakan yang arahnya kepada tujuan dari usulan seseorang, kelompok atau pemerintah di dalam suatu lingkungan tertentu sehubungan dengan adanya hambatan-hambatan tertentu seraya mencari peluang-peluang untuk mencapai suatu tujuan atau terwujudnya sasaran yang diinginkan.

Banyak varibel atau faktor yang memengaruhi keberhasilan suatu implementasi kebijakan pengorganisasian, dan satu sama lain saling terhubung. 
Dimulai dengan implementasi memimpin pelaksanaan dan pengendalian secara rinci seperti implementasi dalam strategi, pengorganisasian, pergerakan bagi kepemimpinan dan pengendalian akan berjalan lancar sesuai tujuan.

Menurut G. Shabbir Cheema dan Dennis A. Rondinelli (1983) dalam (Subarsono, 2005) mengungkapkan bahwa ada 4 (empat) kelompok variable yang dapat memengaruhi kinerja dan dampak suatu program, yakni:

1. Kondisi lingkungan;

2. Hubungan antar organisasi;

3. Sumberdaya organisasi untuk implementasi program

4. Karakteristik dan kemampuan agen pelaksana.

Alasan menggunakan teori implementasi adalah tingkat kesadaran mahasiswa atas pajak terkait dengan didirikannya sebuah sarana pendidikan dan sosialisasi perpajakan dalam perguruan tinggi. Pemerintah telah melakukan suatu tindakan yang bertujuan untuk mewujudkan meningkatnya penerimaan negara atas pajak. Kebijakan yang dikeluarkan pemerintah tentang pajak untuk ditaati oleh Wajib Pajak, salah satunya dengan cara pemerintah mengimplementasikannya melalui program pendidikan dan sosialisasi perpajakan dengan menyediakan sarana perpajakan untuk mahasiswa dengan program tax center.

\section{Pajak}

Menurut (Budi, 2017), di dalam konstitusi Indonesia Perubahan Ketiga Undang-undang Dasar 1945 (2001), terkhusus pada pasal 23A, bahwa "Pajak dan pungutan lain yang bersifat memaksa untuk keperluan negara diatur dengan undang-undang. Secara definisi, Pajak memiliki pengertian yang tercantum dalam Undang-undang No. 28 Thn 2007, "Pajak merupakan kontribusi wajib kepada negara yang terutang oleh orang pribadi atau badan yang sifatnya memaksa berdasarkan aturan perundangan, dengan tidak secara langsung mendapat imbalan dan akan digunakan untuk keperluan negara bagi sebesar-besarnya kemakmuran rakyat."

Dari definisi di atas, maka dapat ditarik kesimpulan bahwa unsur-unsur pajak, adalah:

1. Bersifat wajib dan memaksa

Maka pajak dan pungutan lainnya dilakukan dengan sifat memaksa.

2. Didasarkan pada aturan perundangan

Pajak dan pungutan lain diterima negara dengan dasar kekuatan hokum yang terdapat dalam peraturan perundangan.

3. Imbalan tidak secara langsung

Pajak dan pungutan lain yang dibayar oleh orang pribadi maupun badan tidak akan dirasakan langsung imbalannya oleh mereka.

4. Dipergunakan untuk keperluan Negara

Pajak dan pungutan lain yang diterima Negara akan dipergunakan untuk biaya Negara bagi sebesar-besarnya kemakmuran rakyat.

\section{Tax Center}

Direktorat Jenderal Pajak meresmikan suatu lembaga pelayanan pajak di lingkungan perguruan tinggi melalui Direktorat Jenderal Pajak (DJP) atau Ikatan

* Corresponding author's e-mail: elen.akuntan@gmail.com

http://openjournal.unpam.ac.id/index.php/JIA 
Akuntansi Indonesia (IAI) yang berfungsi sebagai pusat pendidikan dan informasi perpajakan yang ditujukan kepada seluruh civitas academica perguruan tinggi. Menurut Kabid P2Humas Kantor Wilayah Ditjen Pajak (Kanwil DJP) Jakarta Timur, tax center adalah wadah yang kegiatannya bersifat pusat pendidikan, pelatihan, dan informasi terkait perpajakan. Tax center ini ditujukan agar dapat memberikan persepsi positif pada mahasiswa dibidang perpajakan untuk meningkatkan kesadaran mahasiswa untuk membayar pajak dimasa yang akan datang. (Setiawan, 2018)

\section{Pendidikan Pajak}

Menurut (Idi, 2011), definisi pendidikan adalah sesuatu usaha secara sadar oleh orang dewasa dan sengaja juga bertanggungjawab hingga membuat dewasa anak dan berlangsung secara berkelanjutan atau terus menerus.

Sehingga dari definisi tersebut, menjelaskan bahwa:

1. Usaha sadar, maksudnya terjadi situasi pendidikan yang dilaksanakan dalam kesadaran pendidik;

2. Orang dewasa, maksudnya pelaksanaan pendidikan seharusnya orang yang telah dewasa.

3. Disengaja, maksudnya bahwa proses pendidikan memang secara sengaja yang sistematis dan matang.

4. Bertanggungjawab, maksudnya semua tindakan dalam pendidikan harus dapat dipertanggungjawabkan secara moral dengan dasar kaidah atau norma yang berlaku.

5. Dewasa, maksudnya untuk tujuan secara psikis dan fisik yang diwarnai oleh nilai-nilai bangsanya untuk itu di Indonesia harus diwarnai Pancasila dan UUD 1945.

6. Terus menerus, maksudnya: Pendidikan dilaksanakan secara berkesinambungan dan tidak ada hentinya (seumur hidup)

Maka dapat diambil kesimpulan bahwa pendidikan pajak merupakan usaha sadar dan terencana melalui proses pembelajaran oleh pendidik kepada peserta didik tentang perpajakan yang bertujuan untuk menambah ilmu pengetahuan pajak dan membimbing mahasiswa menuju terbentuknya sumber daya manusia yang jujur dan berintegrasi untuk menjadi generasi Wajib Pajak selanjutnya yang sadar akan pajak.(Baykan \& Cek, 2019) bahwa siswa yang mendapatkan pendidikan pajak menunjukan tingkat kesadaran dan persepsi pajak yang rendah, sehingga diharapkan kesadaran pajak melalui pendidikan harus lebih dini lagi tidak sekedar di perguruan tinggi.

Penelitian dari (GERGERLİĞLLU \& AYTAÇ, 2021) memberi gambaran bahwa pendidikan (untuk level pendidikan tinggi) memberi peran penting dalam peningkatan kesadaran akan pajak. Dalam penelitian ini pendidikan lain yang dimaksud yang memberi dampak pada kesadaran adalah pendidikan dalam keluarga. 


\section{Pelatihan Pajak}

Menurut (Mondy, 2011), pelatihan merupakan aktivitas-aktivitas yang dirancang untuk memberi para pembelajar pengetahuan dan keterampilan yang dibutuhkan untuk pekerjaan mereka saat ini.

Menurut (Mondy, 2011) terdapat faktor-faktor yang memengaruhi pelatihan, yaitu:

1. Dukungan manajemen puncak, agar program pelatihan dapat berhasil dibutuhkan dukungan kepemimpinan dari atas;

2. Komitment para spesialis dan generalis, para spesialis dan generalis harus berkomitment pada dan terlibat dalam proses pelatihan;

3. Kemajuan teknologi, yang memberi pengaruh yang sangat besar terhadap pelatihan;

4. Komplesitas organisai, struktur organisasi yang lebih datar karena lebih sedikitnya level manajerial yang membuat lebih sederhana pengaturan orangorang dan tugas-tugas.

Berdasarkan penjelasan di atas maka pelatihan pajak dapat diartikan sebagai suatu kegiatan perpajakan yang dilakukan oleh individu untuk meningkatkan kemampuan diri berupa pengetahuan, keahlian yang dapat diterapkan dalam bidang perpajakan untuk mencapai tujuan tertentu. Sebagai upaya pemerintah memberikan kegiatan kepada mahasiswa dengan tujuan untuk melatih mahasiswa mengenal dunia perpajakan agar mahasiswa dapat merasakan manfaat dari pajak itu sendiri.

Sedangkan menurut penelitian (Bergman, Denning, \& Manoli, 2019) bahwa informasi tentang manfaat pajak untuk keringanan biaya kuliah tidak terlalu sampai ke calon mahasiswa, ini menandakan bahwa informasi tentang manfaat pajak belum diketahui secara luas. Sedangkan penting bagi mahasiswa sejak awal mendapatkan pengetahuan apa manfaat pajak dan kapan manfaat itu bisa dinikmati untuk mencoba mendekati mahasiswa tentang apa itu penerimaan negara dan pajak.

\section{Pengkajian Pajak}

Menurut (Carpenito \& Moyet, 2007), pengkajian merupakan tahap awal yang sistematis dalam mengumpulkan data tentang individu, keluarga dan kelompok. Pengkajian dilakukan bertujuan untuk mengevaluasi dan mengidentifikasi suatu kesalahan dengan cara mengumpulkan data objektif dan subjektif dari masyarakat. Hal-hal yang perlu diperhatikan selama pengkajian adalah:

1. Memahami secara keseluruhan situasi yang sedang dihadapi masyarakat;

2. Mengumpulkan semua informasi yang bersangkutan dengan kesalahan dan/atau masalah yang terjadi dimasa lalu ataupun masalah yang akan timbul dimasa yang akan datang.

Pengkajian pajak merupakan suatu proses mengumpulkan data yang diterima oleh Direktorat Jenderal Pajak berupa saran dan/atau masukan yang bertujuan untuk mengevaluasi sistem atau pelayanan perpajakan dan memperbaiki segala masalahmasalah atau kesalahan sistem maupun perlayanan perpajakan.

Menurut KMK RI nomor 218/KMK.01/2003 menimbang bahwa dalam upaya peningkatan penerimaan negara dari sektor perpajakan, diperlukan peningkatan kualitas telaahan dalam rangka pemecahan konseptual secara keahlian

* Corresponding author's e-mail: elen.akuntan@gmail.com http://openjournal.unpam.ac.id/index.php/JIA 
dibidang perpajakan. Dengan itu, pemerintah membentuk kelompok tenaga pengkaji yang bertugas untuk mengkaji masalah-masalah perpajakan di bidang ekstensifikasi dan intensifikasi pajak, pengawasan dan penegakan hukum perpajakan, pembinaan dan penertiban sumber daya manusia, dan pelayanan perpajakan serta memberikan penalaran pemecahan konseptual secara keahlian.

Dalam penelitian (Kim, Schmöcker, Fujii, \& Noland, 2013) mengisyaratkan bahwa pengambil keputusan atau regulator yang berkaitan dengan kebijakan penetapan harga atau perpajakan harus mempertimbangkan pentingnya sikap masyarakat umum agar percaya kepada institusi pemerintah. Karena dari hasil penelitian menggambarkan bahwa masyarakat umum tidak muncul kesadaran akan lingkungan dan sosial karena tidak percaya kepada pemerintahannya dalam hal ini yang membuat kebijakan.

Sehingga bisa dikatakan, penting bagi pemerintah untuk mengetahui apakah masyarakat sebenarnya mempunyai kepercayaan yang tinggi atau rendah kepada pemerintah terkait ketentuan perpajakan, yang membuat masyarakat menjadi muncul kesadaran akan pajak.

\section{Kesadaran Mahasiswa atas Pajak}

Menurut (Rahayu, 2017), munculnya kesadaran dari wajib pajak ditunjukan dengan kondisi yang mana wajib pajak memiliki pengertian dan paham akan arti, fungsi serta tujuan pembayaran pajak kepada negara. Sehingga diharapkan ketika kesadaran wajib pajak sudah muncul dan tinggi maka memberi pengaruh tingginya peningkatan kepatuhan atas pajak.

Dalam hal ini maka faktor-faktor yang dapat meningkatkan kesadaran wajib pajak, melalui: Dilakukannya sosialisasi tentang perpajakan, pelayanan yang berkualitas, individu wajib pajak yang berkualitas, meningkatkan pengetahuan dari wajib pajak, meningkatnya ekonomi dari wajib pajak, persepsi yang baik akan penerapan dari sistem perpajakan.

Kesadaran mahasiswa merupakan perilaku atau sikap mahasiswa sebagai wajib pajak memiliki rasa ingin untuk memenuhi kewajiban perpajakannya secara jujur dan sukarela dengan merasakan pengaruh membayar pajak untuk negara. Meningkatkan pengetahuan mahasiswa atas perpajakan melalui pendidikan formal maupun non-formal akan berdampak positif terhadap kesadaran mahasiswa untuk melaporkan penghasilannya dan memenuhi kewajibannya sebagai wajib pajak kelak.

\section{Pengembangan Hipotesis}

Pengaruh pendidikan pajak terhadap kesadaran mahasiswa atas pajak.

Proses pendidikan dalam pengubahan sikap dan tata laku seorang Wajib Pajak atau kelompok Wajib Pajak dalam usaha mencerdaskan manusia melalui upaya pengajaran. Berdasarkan penelitian dari Qomariah (2008) dan ratri (2018) diketahui bahwa tingkat pendidikan berpengaruh terhadap kesadaran membayar pajak Dengan adanya pendidikan pajak, mahasiswa dapat memahami pengetahuan tentang perpajakan dan merasakan manfaatnya, maka dalam diri mahasiswa akan timbul keyakinan untuk memenuhi kewajiban perpajakannya kelak. Oleh karena itu, dirumuskan hipotesis sebagai berikut:

H1: Pendidikan pajak berpengaruh positif dan signifikan terhadap kesadaran mahasiswa atas pajak.

* Corresponding author's e-mail: elen.akuntan@gmail.com

http://openjournal.unpam.ac.id/index.php/JIA 


\section{Pengaruh pelatihan pajak terhadap kesadaran mahasiswa atas pajak.}

Selain melalui pendidikan dengan memberikan pendidikan tentang pajak kepada mahasiswa, pemerintah juga melakukan sosialisasi pajak dengan memberi kesempatan untuk mahasiswa terjun langsung untuk melayani Wajib Pajak melaporkan SPT di Kantor Pelayanan Pajak.Dengan terlatihnya mahasiswa dengan kegiatan pelatihan pajak, diharapkan mahasiswa dapat memahami bahwa sudah menjadi kewajiban Wajib Pajak untuk membayar pajak. Hasil penelitian sukowidyanti (2019) dan Widowati (2015) pelatihan perpajakan terbukti berpengaruh dan dapat meningkatkan kesadaran pajak. Oleh karena itu, dirumuskan hipotesis sebagai berikut:

H2: Pelatihan pajak berpengaruh positif dan signifikan terhadap kesadaran mahasiswa atas pajak.

\section{Pengaruh pengkajian pajak terhadap kesadaran mahasiswa atas pajak}

Pengkajian pajak merupakan pelayanan pajak yang diberikan pemerintah untuk mengevaluasi atau memperbaiki masalah-masalah perpajakan yang terjadi. Pemerintah menampung segala saran dan/atau masukan yang diberikan oleh Wajib Pajak guna dapat meningkatkan kepuasan Wajib Pajak atas pelayanan yang diberikan oleh pemerintah dengan itu dapat pula meningkatkan kemauan Wajib Pajak untuk membayar pajak. Kualitas pelayanan pajak yang diberikan oleh aparat pajak mampu menumbuhkan motivasi wajib pajak sehingga mereka akan berusaha memenuhi kewajiban perpajakannya tanpa perlu adanya paksaan, (Caroko, et al., 2015). Oleh karena itu, dirumuskan hipotesis sebagai berikut:

H3: Pengkajian pajak berpengaruh positif dan signifikan terhadap kesadaran mahasiswa atas pajak.

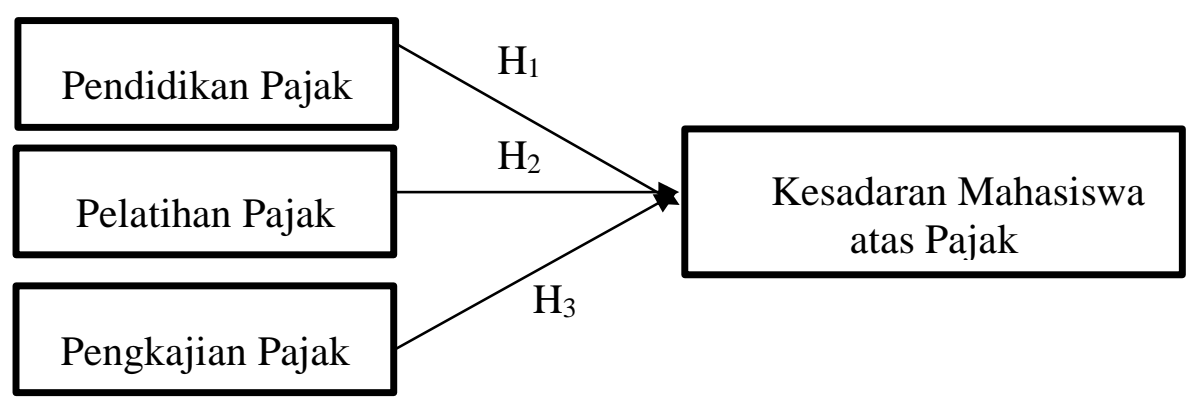

Gambar 1: Rerangka Pemikiran

\section{METODE PENELITIAN}

Penelitian ini menggunakan data primer dengan menggunakan kuesioner. Pada penelitian ini, yang menjadi responden dan subjek penelitian adalah mahasiswa yang terdaftar dan aktif dalam program tax center di kampus atau perguruan tinggi di wilayah Jakarta.

Karena populasi pada penelitian ini sangat luas dan besar serta jumlah dari populasi tersebut tidak diketahui secara pasti, sehingga sampel yang digunakan adalah mahasiswa yang terdaftar dan aktif dalam program tax center di perguruan tinggi di wilayah Jakarta.

* Corresponding author's e-mail: elen.akuntan@gmail.com

http://openjournal.unpam.ac.id/index.php/JIA 
Pengambilan sampel menggunakan teknik Accidental Sampling adalah teknik dimana menentukan sampel yang didasarkan kebetulan, yaitu mahasiswa yang secara kebetulan bertemu dengan peneliti dapat digunakan sebagai sampel, bila dipandang orang yang kebetulan ditemui itu cocok sebagai sumber data. Bentuk cara pengambilan sampel ini termasuk ke dalam non-probability sampling dimana anggota unit sampel yang ditarik mudah dihubungi atau didapat, serta mudah diukur dan bersifat kooperatif.

Variabel Independen

Variabel independen yang lebih sering dikenal dengan variabel stimulus, predictor, antecendent. Di dalam bahasa Indonesia sering juga disebut sebagai variabel bebas. Variabel bebas merupakan variabel yang dapat memengaruhi atau yang menjadi sebab perubahannya atau timbul variabel dependen (terikat). Variabel Independen (bebas) adalah variabel yang menjelaskan atau memengaruhi variabel yang lain, (Sudaryono, 2018).

Variabel independen dalam penelitian ini yaitu :

a) Pendidikan pajak

Pendidikan pajak merupakan studi yang membahas tentang perpajakan guna meningkatkan pengetahuan pajak mahasiswa. Sehingga indikator pendidikan, yaitu : studi dan pengetahuan.

b) Pelatihan pajak

Pelatihan pajak merupakan usaha sosialisasi pajak yang dilakukan oleh pemerintah guna memberikan mahasiswa untuk berperan aktif dalam pelaksanaan kegiatan perpajakan. Sehingga indikator pelatihan, yaitu: Sosialisasi dan kegiatan

c) Pengkajian pajak

Pengkajian pajak merupakan suatu proses evaluasi pemerintah untuk menerima saran dan/atau masukan serta memperbaiki masalah-masalah perpajakan yang dialami oleh masyarakat. Sehingga indikator pengkajian, yaitu: pelayanan dan evaluasi

Variabel Dependen

Variabel dependen (tergantung) adalah variable yang dijelaskan atau yang dipengaruhi oleh variable independen. Penjelasan suatu fenomena tertentu secara sistematis digambarkan dengan variable-variabel dependen. Variabel dependen dalam penelitian ini adalah kesadaran mahasiswa atas pajak, (Sudaryono, 2018).

Kesadaran pajak merupakan keadaan dimana individu tersebut sadar dan ingin melakukan kewajiban perpajakannya secara sukarela dan jujur. Sehingga indikator kesadaran, yaitu: memahami; melaksanakan; dan melaporkan.

\section{HASIL DAN PEMBAHASAN}

\section{Statistik Deskriptif}

Gambaran umum mengenai karakteristik responden dijelaskan dengan tabel statistik deskriptif responden yang diukur dengan skala ukur interval yang menjelaskan besarnya frekuensi absolute dan persentase jenis kelamin, nama 
kampus, program studi, periode semester, lama aktif di tax center, sedangkan untuk memberikan deskriptif mengenai variabel independen penelitian yaitu pendidikan pajak, pelatihan pajak dan pengkajian pajak.

Tabel 1 Deskripsi Responden

\begin{tabular}{|c|c|c|c|}
\hline Jenis Kategori & Keterangan & Jumlah & Presentase \\
\hline \multirow[t]{2}{*}{ Jenis Kelamin } & 1. Laki-laki & 38 & $37,6 \%$ \\
\hline & 2. Perempuan & 63 & $62,4 \%$ \\
\hline \multirow[t]{13}{*}{ Universitas } & 1. Gunadarma & 20 & $19,8 \%$ \\
\hline & 2. Mercu Buana & 17 & $16,8 \%$ \\
\hline & 3. Pancasila & 14 & $13,9 \%$ \\
\hline & 4. Nasional & 10 & $9,9 \%$ \\
\hline & 5. UPN Veteran Jakarta & 9 & $8,9 \%$ \\
\hline & 6. Trisakti & 8 & $7,9 \%$ \\
\hline & 7. $\mathrm{Al}$ - Azhar & 7 & $6,9 \%$ \\
\hline & 8. Perbanas Institute & 4 & $4,0 \%$ \\
\hline & 9. Budi Luhur & 4 & $4,0 \%$ \\
\hline & 10. Binus University & 4 & $4,0 \%$ \\
\hline & 11. Kristen Krida Wacana & 2 & $2,0 \%$ \\
\hline & 12. Satya Negara Indonesia & 1 & $1,0 \%$ \\
\hline & 13. Paramadina & 1 & $1,0 \%$ \\
\hline \multirow[t]{4}{*}{ Program Studi } & 1. $\quad$ Akuntansi & 69 & $68,3 \%$ \\
\hline & 2. Manajemen & 20 & $19,8 \%$ \\
\hline & 3. Perpajakan & 8 & $7,9 \%$ \\
\hline & 4. Lain-lain & 4 & $4,0 \%$ \\
\hline \multirow[t]{5}{*}{ Semester } & 1. $1-2$ & 7 & $6,9 \%$ \\
\hline & 2. $3-4$ & 24 & $23,8 \%$ \\
\hline & 3. $5-6$ & 25 & $24,8 \%$ \\
\hline & 4. $7-8$ & 42 & $41,6 \%$ \\
\hline & 5. $>8$ & 3 & $3,0 \%$ \\
\hline \multirow{2}{*}{$\begin{array}{l}\text { Lama Aktif Terdaftar di } \\
\text { Tax Center }\end{array}$} & 1. $<1$ tahun & 72 & $71,3 \%$ \\
\hline & 2. $>1$ tahun & 29 & $28,7 \%$ \\
\hline
\end{tabular}

Sumber : Data Primer Diolah

Tabel 2 Statistik DeskriptifVariabel Penelitian

\begin{tabular}{lccccc}
\hline \multicolumn{1}{c}{ Variabel } & $\mathrm{N}$ & Minimum & Maximum & Mean & $\begin{array}{c}\text { Standard } \\
\text { Deviation }\end{array}$ \\
\hline Pendidikan Pajak & 101 & 20 & 35 & 30,50 & 3,665 \\
Pelatihan Pajak & 101 & 16 & 30 & 25,77 & 3,343 \\
$\begin{array}{l}\text { Pengkajian Pajak } \\
\text { Kesadaran Mahasiswa }\end{array}$ & 101 & 10 & 20 & 16,81 & 2,353 \\
terhadap Pajak & 101 & 25 & 45 & 37,89 & 4,823 \\
\hline
\end{tabular}

Sumber : Data Primer Diolah

Tabel 2 menjelaskan bahwa pada variabel pendidikan pajak jawaban minimum responden sebesar 20 dan maksimum sebesar 35, dengan rata-rata total jawaban 30,5 dan standar deviasi sebesar 3,665. Variabel pelatihan pajak jawaban minimum responden sebesar 16 dan maksimum sebesar 30, dengan rata-rata total jawaban 25,77 dan standar deviasi sebesar 3,343.

Variabel Pengkajian Pajak jawaban minimum responden sebesar 10 dan maksimum sebesar 20, dengan rata-rata minimum responden sebesar 16,81 dan standar deviasi sebesar 2,353. Sedangkan variabel kesadaran mahasiswa terhadap pajak minimum responden sebesar 25 dan maksimum sebesar 45, dengan rata-rata total jawaban 37,89 dan standar deviasi sebesar 4,823. 


\section{Uji Kualitas Data}

Uji kualitas data menggunakan uji validitas dan uji reliabilitas. Uji validitas digunakan untuk mengukur valid atau tidak validnya suatu kuesioner penelitian. Dalam penelitian ini, pengumpulan data menggunakan kuesioner. Sedangkan uji reliabilitas merupakan alat untuk mengukur yang digunakan tepat untuk mengukur konsep yang hendak diukur dan menunjukan sejauh mana suatu hasil pengukuran relatif konsisten apabila pengukuran dilakukan berulang kali.

Tabel 3 Hasil Uji Kualitas Data

\begin{tabular}{lcc}
\hline \multicolumn{1}{c}{ Variabel } & Jumlah Indikator & Keterangan \\
\hline Pendidikan Pajak & 7 & Valid \& Reliabel \\
Pelatihan Pajak & 6 & Valid \& Reliabel \\
Pengkajian Pajak & 4 & Valid \& Reliabel \\
Kesadaran Mahasiswa atas Pajak & 9 & Valid \& Reliabel \\
\hline
\end{tabular}

Sumber: Data primer yang diolah

\section{Uji Asumsi Klasik}

Uji asumsi klasik meliputi uji multikolinieritas, uji heteroskedastisitas, dan uji normalitas. Untuk mendapatkan ketepatan model yang akan dianalisis dalam penelitian ini perlu dilakukan pengujian atas beberapa persyaratan asumsi klasik yang mendasari model regresi. Uji Multikolinearitas menggunakan Variance Inflation Factor (VIF), uji heteroskedastisitas menggunakan model regresi, dan uji normalitas menggunakan Grafik P-plot.

Berdasarkan hasil uji multikolinieritas, diperoleh nilai pada tolerance pada semua variabel di atas 0,01, dan nilai VIF di bawah 10. Maka dari hasil tersebut dapat disimpulkan bahwa tidak ada terjadinya multikolinieritas antar variabel bebas satu sama lainnya. Hasil uji Heteroskedastisitas menunjukkan tidak terjadi heteroskedatisitas karena nilai sig. antara variabel independen yaitu pendidikan pajak, pelatihan pajak dan pengkajian pajakmemiliki nilai absolut residual $>0,05$ maka dapat dikatakan variabel independen dalam penelitian ini tidak terjadi heteroskedatisitas.Sedangkan dari hasil uji Normalitas diperoleh bahwa nilai signifikansi lebih besar dari $0,05(0,43>0,05)$, maka dapat dinyatakan bahwa nilai residual berdistribusi normal.

\section{Analisis Regresi dan Hipotesis}

Uji F

Uji statistik $\mathrm{F}$ digunakan untuk mengetahui pengaruh semua variabel independen yang dimasukkan dalam model regresi secara bersama-sama terhadap variabel dependen yang diuji pada tingkat signifikansi 0,05 .

Tabel 4 Hasil Uji Statistik F ANOVA $^{\mathrm{a}}$

\begin{tabular}{lrrrrr}
\hline Model & Sum of Squares & \multicolumn{1}{c}{ Df } & Mean Square & F & Sig. \\
\hline 1 Regression & 1513.582 & 3 & 504.527 & 60.254 & $.000^{\mathrm{b}}$ \\
Residual & 812.220 & 97 & 8.373 & & \\
Total & 2325.802 & 100 & & & \\
\hline
\end{tabular}

Sumber : Data Primer Diolah 


\section{Uji t (parsial)}

\begin{tabular}{|c|c|c|c|c|c|c|}
\hline \multicolumn{7}{|c|}{$\begin{array}{c}\text { Tabel } 5 \text { Hasil Uji Statistik T } \\
\text { Coefficients }^{\mathbf{a}}\end{array}$} \\
\hline & \multirow[b]{2}{*}{ Model } & \multicolumn{2}{|c|}{$\begin{array}{l}\text { Unstandardized } \\
\text { Coefficients }\end{array}$} & \multirow{2}{*}{$\begin{array}{c}\text { Standardized } \\
\text { Coefficients } \\
\text { Beta }\end{array}$} & \multirow[b]{2}{*}{$\mathrm{T}$} & \multirow{3}{*}{$\begin{array}{r}\text { Sig. } \\
.024\end{array}$} \\
\hline & & B & Std. Error & & & \\
\hline & (Constant) & 5.688 & 2.488 & & 2.286 & \\
\hline & Pendidikan Pajak (X1) & .233 & .147 & .177 & 1.585 & .116 \\
\hline & Pelatihan Pajak (X2) & .575 & .174 & .399 & 3.312 & .001 \\
\hline & Pengkajian Pajak (X3) & .611 & .191 & .298 & 3.194 & .002 \\
\hline
\end{tabular}

Berdasarkan hasil uji t pada tabel di atas, pada masing - masing variabel dapat diinterpretasikan bahwa pelatihan pajak, pengkajian pajak, berpengaruh positif dan signifikan terhadap kesadaran mahasiswa ataspajak, sedangkan pendidikan pajak tidak memiliki pengaruh.

\section{Uji Koefisien Adjusted R Square}

Tabel 6 Hasil Uji Koefisien Adjusted R Square Model Summary

\begin{tabular}{|c|c|c|c|c|}
\hline Model & $\mathrm{R}$ & R Square & $\begin{array}{l}\text { Adjusted } \\
\text { R Square }\end{array}$ & $\begin{array}{l}\text { Std. Error of the } \\
\text { Estimate }\end{array}$ \\
\hline 1 & $.807^{\mathrm{a}}$ & .651 & .640 & 2.894 \\
\hline
\end{tabular}

Sumber : Data Primer Diolah

Berdasarkan tabel 6 di atas diketahui besarnya nilai adjusted Rsquaresebesar 0,640 hal ini berarti $64 \%$ variabel dependen kesadaran mahasiswa atas pajak dapat dijelaskan oleh variabel independen yang meliputi pendidikan pajak, pelatihan pajak, dan pengkajian pajak dan terdapat $36 \%$ varians variabel dependen yang dijelaskan oleh faktor lain seperti sikap jujur dan taat mahasiswa atas kewajibannya sebagai Wajib Pajak.

\section{Pembahasan}

\section{Pengaruh Pendidikan Pajak terhadap Kesadaran Mahasiswa atas Pajak}

Hasil uji t variabel pendidikan pajak menunjukkan bahwa tidak terdapat pengaruh positif dan signifikan terhadap kesadaran mahasiswa atas pajak. Hasil penelitian ini tidak sejalan dengan penelitian dari (GERGERLİĞLU \& AYTAÇ, 2021) memberi gambaran bahwa pendidikan (untuk level pendidikan tinggi) memberi peran penting dalam peningkatan kesadaran akan pajak.

Hasil penelitian ini sejalan dengan hasil penelitian yang dilakukan oleh(Istanto, 2010). Menurut (Istanto, 2010), tingkat pendidikan tidak berpengaruh secara signifikan terhadap motivasi Wajib Pajak dalam membayar pajak. Juga sejalan dengan hasil penelitian (Baykan \& Cek, 2019) bahwa siswa yang mendapatkan pendidikan pajak menunjukan tingkat kesadaran dan persepsi pajak yang rendah, sehingga diharapkan kesadaran pajak melalui pendidikan harus lebih dini lagi tidak sekedar di perguruan tinggi. Dan ilmu kesadaran dan persepsi pajak harus menjadi mata kuliah wajib di luar dari mata kuliah pajak itu sendiri. 
Berdasarkan data responden yaitu $68,3 \%$ merupakan program studi akuntansi, dan $80 \%$ lebih responden sudah berada di semester 3 ke atas, yang seharusnya sudah mendapatkan ilmu pajak di kelas. Namun, ternyata hasil uji t variable pendidikan pajak dimana salah satu pernyataan yang dimunculkan adalah pendidikan pajak harus dilakukan sejak dini seperti yang di dapat di sekolah formal (kampus).

\section{Pelatihan Pajak terhadap Kesadaran Mahasiswa atas Pajak}

Hasil uji t variabel pelatihan pajak menunjukkan bahwa terdapat pengaruh positif dan signifikan terhadap kesadaran mahasiswa atas pajak. Hasil penelitian variabel ini konsisten dengan variabel sosialisasi perpajakan pada penelitian yang dilakukan oleh (Widowati, 2015). Menurut (Widowati, 2015), sosialisasi perpajakan berpengaruh signifikan terhadap kepatuhan Wajib Pajak.

Berdasarkan data responden dalam penelitian ini sebesar $72 \%$ aktif di tax center di bawah 1 tahun, maka mereka beranggapan mereka membutuhkan wadah pelatihan untuk bisa meningkatkan kesadaran dan juga pemahaman mereka atas pajak. Meskipun demikian mayoritas responden sudah mendapatkan penjelasan tentang pajak di tax center.

\section{Pengkajian Pajak terhadap Kesadaran Mahasiswa atas Pajak}

Hasil uji t, bahwa Pengkajian Pajak memiliki pengaruh positif dan signifikan terhadap Kesadaran Mahasiswa atas Pajak. Pengkajian merupakan tahap awal yang sistematis dalam mengumpulkan data tentang individu, keluarga dan kelompok.

Hasil penelitian ini sejalan dengan variabel pelayanan perpajakan pada penelitian yang dilakukan oleh(Siregar, Saryadi, \& Lystiorini, 2012). Menurut (Siregar, Saryadi, \& Lystiorini, 2012) pelayanan fiskus berpengaruh signifikan terhadap kepatuhan Wajib Pajak. Berdasarkan data responden penelitian yaitu mahasiswa yang terdaftar aktif dalam tax center $<1$ tahun dengan jumlah 72 responden atau sebesar $71,3 \%$ yang menganggap bahwa salah satu faktor untuk meningkatkan kesadaran pajak dengan memberikan pelayanan yang baik kepada Wajib Pajak.

\section{KESIMPULAN}

\section{Kesimpulan}

Pendidikan pajak yang didapat mahasiswa khususnya mahasiswa Prodi Akuntansi tidak memiliki pengaruh positif dan signifikan terhadap kesadaran mahasiswa atas pajak. Sedangkan Pelatihan dan Pengkajian pajak memiliki pengaruh positif dan signifikan terhadap kesadaran mahasiswa atas pajak.

\section{Keterbatasan}

Penelitian ini memiki jumlah populasi yang tidak pasti dan menggunakan sampel hanya di 13 perguruan tinggi di Jakarta dan dikarenakan keterbatasan waktu yang dimiliki penulis dalam penyebaran kuesioner sehingga tidak dapat mengumpulkan responden sesuai dengan jumlah minimum yang ditentukan. 


\section{Saran}

Penelitian selanjutnya agar menambahkan variabel lainnya yang dapat mengukur kesadaran mahasiswa atas pajak secara akurat, dengan memperluas ruang lingkup sampel dan dapat membandingkan tax center pada perguruan tinggi satu dengan lainnya di seluruh Indonesia.

\section{Implikasi}

a) Bagi Akademisi

Penelitian ini memberikan dampak kepada pendidik agar mahasiswa bisa mendapatkan ilmu dalam bidang perpajakan tidak hanya sekedar di kelas, melalui tax center dengan peran yang lebih luas lagi misal dengan membuka ruang konsultasi bagi pengusaha. Konsultasi dilakukan oleh mahasiswa yang didampingi dosen yang berpengalaman, agar mahasiswa bisa secara langsung dapat mengetahui dan memahami kasus-kasus yang terjadi di perusahaan. Karena permasalahan pajak lebih banyak mengikat pada siklus akuntansi di perusahaan.

b) Bagi Asosiasi Tax Center Perguruan Tinggi Seluruh Indonesia (ATPETSI)

Dengan hasil penelitian ini diharapkan peran dari ATPETSI yang selama ini lebih mengedepankan sosialisasi dan edukasi, bisa menambahkan 1 peran lagi yaitu konsultasi. Konsultasi dari mahasiswa yang didampingi dosen bagi pengusaha-pengusaha khususnya skala UMKM.

\section{DAFTAR PUSTAKA}

Baykan, H., \& Cek, K. (2019). University Students' Perceptions and Awareness of Tax. IIOAB Journal (A Journal Of Multidisciplinary Science and Technology), 10 (Multidisciplinary Social Sciences and Economics), 157-160.

Bergman, P., Denning, J. T., \& Manoli, D. (2019). Is Information Enough? The Effect of Information about Education Tax Benefits on Student Outcomes. Journal of Policy Analysis and Management, 38 (3), 706-731.

Budi, P. (2017). Buku Pintar Pajak (Edisi 2. vyd.). Jakarta, DKI Jakarta, Indonesia: PT Pratama Indomitra Konsultan.

Caroko, B. (2015). Pengaruh pengetahuan perpajakan, kualitas pelayanan pajak dan sanksi pajak terhadap motivasi wajib pajak orang pribadi dalam membayar pajak. Jurnal Mahasiswa Perpajakan, 4(1).

Carpenito, \& Moyet. (2007). Diagnosis Keperawatan. Jakarta: EGC.

DJP. (2019). Načteno z DJP: https://pajak.go.id/

GERGERLİĞLU, U., \& AYTAÇ, D. (2021). The Measurement of The Students' Attitudes Regarding Tax Consciousness: A Case Study. Journal Of Social Sciences, 6 (1), 59-78.

Herryanto, M., \& Toly, A. A. (2013). Pengaruh Kesadaran Wajib Pajak, Kegiatan Sosialisasi Perpajakan, dan Pemeriksaan Pajak terhadap Penerimaan Pajak 
Jurnal Ilmiah Akuntansi Universitas Pamulang - Vol. 9, No. 2Juli 2021 - Komala \& elen

Penghasilan di KPP Pratama Surabaya Sawahan. Tax \& Accounting Review, Vol. 1; No. 1, 124-135.

Idi, A. (2011). Sosiologi Pendidikan. Jakarta: Rajawali Pers.

Istanto, F. (2010). Analisis Pengaruh Pengetahuan tentang Pajak, Kualitas Pelayanan Pajak, Ketegasan Sanksi Perpajakan dan Tingkat Pendidikan terhadap Motivasi Wajib Pajak dalam Membayar Pajak. Načteno z http://repository.uinjkt.ac.id/.

Kim, J., Schmöcker, J.-D., Fujii, S., \& Noland, R. B. (2013). Attitudes towards Road Pricing Environmental Taxationamong U.S. and U.K. Students. 50-62.

Mondy, R. W. (2011). Manajemen Sumber Daya Manusia ( Edisi 10, Jilid satu. vyd.). Jakarta: Erlangga.

Qomariah, S. (2008). Analisis pengaruh pengetahuan tentang pajak dan tingkat pendidikan wajib pajak terhadap kesadaran membayar pajak.

Rahayu, S. K. (2017). Perpajakan (Konsep dan Aspek Formal). Bandung: Rekayasa Sains.

Ratri, Y. I., \& Tjahjono, A. (2018). Analisis Pengaruh Pengetahuan Perpajakan, Sosialisasi, Pelayanan, Sanksi Perpajakan, Dan Tingkat Pendidikan Wajib Pajak, Terhadap Kesadaran Wajib Pajak Membayar Pbb P2 (Doctoral Dissertation, Stie Widya Wiwaha)

Setiawan, D. A. (2. 10 2018). DDTC News. Načteno z DDTC: https://news.ddtc.co.id/

Siregar, Y. A., Saryadi, S., \& Lystiorini, S. (2012). Pengaruh Pelayanan Fiskus dan Pengetahuan Perpajakan terhadap Kepatuhan Wajib Pajak. Jurnal Ilmu Administrasi Bisnis, Volume 1, No 1, 295-304.

Subarsono. (2005). Analisis Kebijakan Publik: Konsep, Teori dan Aplikasi. Yogyakarta: Pustaka Pelajar.

Sudaryono. (2018). Metodologi Penelitian. Depok, Jawa Barat, Indonesia: PT Rajagrafindo Persada.

Sukowidyanti, A. P., Nurlaily, F., \& Aini, E. K. (2019). Pengembangan dan Pelatihan Perpajakan Games Edukasi Perpajakan Untuk Meningkatkan Kesadaran Pajak Early Tax Payer. Jurnal Inovasi Hasil Pengabdian Masyarakat (JIPEMAS), 2(1), 18-30.

Triandani, M., \& Apollo. (2020). Effect The Understanding of Taxation, Tax Sanctions and Taxpayer Awareness of Taxpayer Compliance (Researchon Taxpayers of Individual Enterpreneurs in Tangerang Region). Dinasti International Journal of Digital Business Management , 2 (1), 87-93.

Wahab, S. A. (2012). Analisis Kebijakan. Jakarta: Bumi Aksara.

Widowati, R. (27. November 2015). Kepatuhan Wajib Pajak Melalui Sosialisasi Perpajakan, Sanksi Perpajakan, Pengetahuan Pajak dan Pelayanan Fiskus. Skripsi. Semarang, Jawa Tengah: Universitas Dian Nuswantoro. 